\title{
Gender gap in health condition and quality of life at advanced age
}

\author{
Dorota Raczkiewicz ${ }^{1, A, C-F \oplus}$, Przemysław Bejga ${ }^{2, B-D \oplus}$, Jakub Owoc ${ }^{3, D-E \oplus}$, Mariusz Witczak ${ }^{4, D \oplus}$, \\ Iwona Bojar ${ }^{5, A, C, E-F}($ \\ 1 Institute of Statistics and Demography, Collegium of Economic Analysis, SGH Warsaw School of Economics, Warsaw, \\ Poland \\ ${ }^{2}$ Department of Pharmacology and Toxicology, Faculty of Medicine and Health Sciences, University of Zielona Góra, \\ Poland \\ ${ }^{3}$ National Institute of Geriatrics, Rheumatology and Rehabilitation, Warsaw, Poland \\ ${ }^{4}$ Department of Internal Medicine, Faculty of Medicine and Health Sciences, University of Zielona Góra, Poland \\ ${ }^{5}$ Department of Women's Health, Institute of Rural Health, Lublin, Poland \\ A - Research concept and design, B - Collection and/or assembly of data, C - Data analysis and interpretation, \\ $D$ - Writing the article, E - Critical revision of the article, F- Final approval of article
}

Raczkiewicz D, Bejga P, Owoc J, Witczak M, Bojar I. Gender gap in health condition and quality of life at advanced age. Ann Agric Environ Med. 2020; 27(4): 636-643. doi: 10.26444/aaem/125753

\begin{abstract}
Introduction. Increased life expectancy, share of the very old in populations and differences in the prevalence or types of health problems between male and female seniors pose challenges for health and social care systems in providing adequate care.

Objective. The aim of the study is to compare the health condition and quality of life between women and men aged 90 or over, as well as to correlate the quality of life at advanced age with demographic and health conditions.

Materials and method. The study was conducted in Poland in 2015-2018 on 870 women and 264 men aged 90 or over who were able to communicate logically and had no dementia diagnosed previously by a physician. The author's questionnaire, Katz Index of Independence in Activities of Daily Living, Abbreviated Mental Test Score and WHO Quality of Life-Bref questionnaires were used.

Results. The women aged 90 or over had a significantly higher prevalence of chronic pain ( $76 \%$ vs $60 \%$ ), urinary incontinence (60\% vs $44 \%)$, falls and syncopes (39\% vs $25 \%)$, stool incontinence ( $17 \%$ vs $9 \%)$, more severe functional and cognitive impairment and lower quality of life than men at the same age. City residence, being widowed, chronic pain, geriatric giants and functional impairment were factors found to decrease all aspects of the life quality, while age in the studied interval decreased only physical health' assessment. Lack of education only affected negatively psychological health while cognitive impairment decreased the assessment of physical and psychological health, as well as social relationships.

Conclusion. Men who reached the age of 90 or over assessed their health condition and quality of life better than women at the same age.
\end{abstract}

\section{Key words}

quality of life, state of health, ageing, advanced age, gender gap

\section{INTRODUCTION}

Ageing of the population is a significant issue across many regions, but it is particularly evident in Western European countries which have the highest percentage of people aged 65 or over. The EUROSTAT forecasts a decrease in the working population of Europeans by approximately $6.8 \%$ (20.8 million) by 2030 , and a simultaneous decrease in workers per retiree ratio from 4:1 to 2:1. These trends will continue until around 2060 and will become most dynamic in Central-Eastern European countries [1]. Health problems affecting elderly people, such as geriatric giants, limited daily activities, a need for support and social care, and many others associated with ageing, require solid evaluation: risk stratification and developing action plans and funding estimations. It is therefore worthwhile considering the potential differences in ageing betweenmen and women. The current goal of health and social policies is to shorten a disability period, which is

Address for correspondence: Iwona Bojar, Department of Women's Health, Institute of Rural Health, Jaczewskiego 2, 20-090 Lublin, Poland

E-mail: iwonabojar75@gmail.com

Received: 12.03.2020; accepted: 17.07.2020; first published:02.09.2020 frequently inevitable at the end of one's life, and extend the Healthy Life Years (HLY). In 2016, the HLY at birth in the European Union was estimated at 64.2 for women and 63.5 years for men. However, the HLY for both men and women aged 65 in the $28 \mathrm{EU}$ countries equals 9.4. This means that although men have shorter lives than women, they manage to stay independent and healthy for longer [2]. Hence, ageing and age-related limitations may be associated more with women than men, and caused by the gap in life expectancy between genders [3].

The average life expectancy at birth for an EU citizen born in 2017 was 78.02 years for men and 83.36 years for women. The increase in life expectancy between 2000-2016 totalled 4.03 and 2.88, respectively; therefore, the gender gap is decreasing, indicating a trend rather than a short-term fluctuation $[4$, 5]. In some developed countries, the gap dropped to three ( 84 vs 81 in Israel) or four years ( 83 vs 79 in the UK) [5]. The results of a recent study conducted in Sweden [6] confirmed this phenomenon, especially after adjusting mortality for smoking and other lifestyle-related factors. This may be a gradual paradigm shift; however, it is too soon and too difficult to determine whether the gap will eventually close as there 
are too many factors involved: accidents, lifestyle, substance abuse, social roles or genetics. For example, hormone-related factors (such as the protective role of estrogens in the incidence of cardiovascular diseases) or socio-psychological factors (such as risky behaviour more often witnessed in males) seem to favour longer lives among females [7-11].

The development of medicine over the last decades has also had its impact on the phenomenon of longevity. Healthconscious individuals that live healthy lifestyles and have access to necessary medical procedures are more likely to live longer [12]. How can all these processes further contribute to the closing of the gap in life expectancy between genders is a question to be asked. All we know now for certain is that it can be as low as three years [5].

In 2015, the expected HLY at 65 in Poland was below the EU-28 average for both women (8.4 vs. 9.4) and men (7.6 vs 9.4). The population of $85+$ accounted for $2.02 \%$ in 2018 and was also below the EU-28 average of $2.70 \%$. Nevertheless, the demographic trends for the country are unfavourable as official forecasts predict that the percentage of the population of $80+$ will increase from $3.9 \%$ in 2013 to $10.5 \%$ in 2050 [13].

\section{OBJECTIVE}

The objective of this study was to compare health condition and the quality of life between men and women aged 90 or over, as well as to correlate the quality of life at advanced age with demographic and health conditions.

\section{MATERIALS AND METHOD}

Participants. This study is the second part of a large research project carried out by Prof. Bojar's team. The first part of the project was aimed at evaluating the state of health and quality of life only in women at advanced age, and published by Pinkas, Bojar et al. [14]. While this study is aimed primarily at comparing the health condition and quality of life between men and women, it also focuses on the gender gap.

The study was conducted in Poland in 2015-2018 and organizationally supported by Social Support Centres. These are State funded organizations that offer support to people in difficult life situations, including seniors residing at their homes or with families. The Central Statistical Office in Poland lists 2,500 such centres all around the country. A systematic sample of 250 centres (10\%) was selected from that list. Finally, 153 centres agreed to participate in the study. Each of them received 10 questionnaires with detailed instructions and inclusion (age of 90+, verbal contact) and exclusion criteria (any of the following: dementia previously diagnosed by a physician, no verbal contact, addiction to alcohol, addiction to psychotropic drugs). The participants were selected by staff members who were thoroughly instructed and trained. The training included an e-learning session that explained each question on the questionnaire. Staff were instructed to contact (through phone or e-mail) the research team (psychologist, IT specialist and geriatrician) in case of any uncertainties. The first step in recruiting participants involved verifying whether there was verbal logical contact. If so, the AMTS scale was administered. Participants with scores below 4 points were required to be assisted by a family member or carer familiar with their condition.
A total of 1,134 completed questionnaires were received, a response rate of $56 \%$. The study included 870 women and 264 men aged 90 or over, with demographic data, prevalence of chronic pain, geriatric giants and three standardized tests.

\section{Standardized tests}

Katz Index of Independence in Activities of Daily Living (Katz ADL) was used to evaluate functional impairment. The test involves 6 activities: bathing, dressing, toileting, transferring, continence and feeding. Each of the activities performed independently is rewarded with 1 point. A total score of 2 or less means a severe functional impairment, 3 or 4 - a moderate functional impairment, 5 or 6 - a full function [15].

Abbreviated Mental Test Score (AMTS) was used to evaluate a cognitive status. Respondents were asked about such things as their age or date and time. A total score of 3 or less meant a severe cognitive impairment, 4-6 - moderate cognitive impairment, 7 or 8 - mild cognitive impairment, 9-11 - a normal mental state [16].

World Health Organization Quality of Life - an abbreviated version (WHO-QOL Bref) was used to measure quality of life [17]. It consists of 24 questions investigating overall quality of life, general health, physical health, psychological health, social relationships and environment on a 5-degree scale: very poor (1), poor (2), neither good nor poor (3), good (4), very good (5).

Statistical analyses. Statistical analyses were conducted using STATISTICA software. Median (Me), mean (M) and standard deviation (SD) for numerical variables, as well as absolute numbers (n) and percentages (\%) for categorical variables, were estimated. The following statistical tests were applied: $\chi^{2}$ test of independence to compare categorical variables between men and women, $t$ test to compare numerical variables between men and women or between two categories of categorical variables, $\mathrm{F}$ test to compare numerical variables between more than 2 categories of categorical variables, Pearson's correlation coefficient to determine demographic and health determinants of the assessment of quality of life. Significance level was assumed at 0.05 .

\section{RESULTS}

Study group characteristics. There were 1,134 participants: 870 women $(76.72 \%)$ and 264 men $(23.28 \%)$ aged 90 or over (Tab. 1). The majority of both genders had a low level of education and lived in rural areas with their families. There were significant differences in marital status between them $(\mathrm{p}<0.001)$, with a higher percentage of married men than women $(40 \%$ vs. $4 \%)$, with a larger percentage of women being widowed ( $89 \%$ vs. $56 \%)$.

Health Condition. Chronic pain and the 3 geriatric giants (urinary and stool incontinences, falls and syncopes) were more common in women than they were in men. A similar percentage of both genders suffered from hypoacusis and visual disturbances (Tab. 2). A larger percentage of women suffered from functional impairment measured with Katz ADL (Tab. 3) and cognitive impairment measured with AMTS (Tab. 4) than men. 
Table 1. Sample characteristics

\begin{tabular}{|c|c|c|c|c|c|}
\hline Parameter & Category & Men & Women & Test & $\mathrm{p}$ \\
\hline $\begin{array}{l}\text { Age: } \min - \\
\max , M \pm S D\end{array}$ & years & $\begin{array}{r}90-111 \\
93.9 \pm 2.6\end{array}$ & $\begin{array}{l}91-106 \\
94.3 \pm 2.9\end{array}$ & $\mathrm{t}=2.100$ & 0.036 \\
\hline \multirow{3}{*}{$\begin{array}{l}\text { Place of } \\
\text { residence, } \\
\mathrm{n}(\%)\end{array}$} & rural & $193(73.11)$ & $527(60.57)$ & \multirow{3}{*}{$X^{2}=14.892$} & \multirow{3}{*}{0.001} \\
\hline & $\begin{array}{c}\text { town }(<100,000 \\
\text { inhabitants })\end{array}$ & $50(18.94)$ & $214(24.60)$ & & \\
\hline & $\begin{array}{c}\text { city (> 100,000 } \\
\text { inhabitants) }\end{array}$ & $21(7.95)$ & $129(14.83)$ & & \\
\hline \multirow{4}{*}{$\begin{array}{l}\text { Level of } \\
\text { education, } \\
\mathrm{n}(\%)\end{array}$} & $\begin{array}{l}\text { no school } \\
\text { education }\end{array}$ & 31 (11.74) & $147(16.90)$ & \multirow{4}{*}{$x^{2}=4.665$} & \multirow{4}{*}{0.198} \\
\hline & $\begin{array}{l}\text { primary or } \\
\text { primary not } \\
\text { completed }\end{array}$ & 190 (71.97) & 607 (69.77) & & \\
\hline & secondary & $36(13.64)$ & 95 (10.92) & & \\
\hline & tertiary & $7(2.65)$ & $21(2.41)$ & & \\
\hline \multirow{3}{*}{$\begin{array}{l}\text { Marital } \\
\text { status, } \\
\mathrm{n}(\%)\end{array}$} & married & 105 (39.77) & 33 (3.79) & \multirow{3}{*}{$X^{2}=237.507$} & \multirow{3}{*}{$<0.001$} \\
\hline & never married & $10(3.79)$ & $60(6.90)$ & & \\
\hline & widowed & $149(56.44)$ & 777 (89.31) & & \\
\hline \multirow{3}{*}{ Living } & alone & $60(22.73)$ & $326(37.47)$ & \multirow{3}{*}{$x^{2}=20.149$} & \multirow{3}{*}{$<0.001$} \\
\hline & with family & $195(73.86)$ & $513(58.97)$ & & \\
\hline & in institution & $9(3.41)$ & 31 (3.56) & & \\
\hline
\end{tabular}

Table 2. Prevalence of chronic pain and geriatric giants at advanced age

\begin{tabular}{lcccccc}
\hline \multirow{2}{*}{ Characteristics } & \multicolumn{2}{c}{ Men } & \multicolumn{2}{c}{ Women } & \multirow{2}{*}{ X $^{2}$} & $\mathrm{p}$ \\
\cline { 2 - 5 } & $\mathrm{n}$ & $\%$ & $\mathrm{n}$ & $\%$ & & \\
\hline Chronic pain & 159 & 60.23 & 658 & 75.63 & 24.111 & $<\mathbf{0 . 0 0 1}$ \\
\hline Hypoacusis & 214 & 81.06 & 700 & 80.46 & 0.063 & 0.802 \\
\hline Visual disturbances & 166 & 62.88 & 598 & 68.74 & 2.750 & 0.097 \\
\hline Urinary incontinence & 116 & 43.94 & 525 & 60.34 & 19.824 & $<\mathbf{0 . 0 0 1}$ \\
\hline Falls and syncopes & 66 & 25.00 & 340 & 39.08 & 14.452 & $<\mathbf{0 . 0 0 1}$ \\
\hline Stool incontinence & 24 & 9.09 & 147 & 16.90 & 8.101 & $\mathbf{0 . 0 0 4}$ \\
\hline
\end{tabular}

Table 3. Katz index of independence in Activities of Daily Living (ADL) results at advanced age

\begin{tabular}{|c|c|c|c|c|c|c|c|c|c|}
\hline \multirow{2}{*}{$\begin{array}{l}\text { Severity of } \\
\text { functional } \\
\text { impairment }\end{array}$} & \multicolumn{2}{|c|}{ Men } & \multicolumn{2}{|c|}{ Women } & \multirow{2}{*}{$\begin{array}{c}\text { No. of ADLs } \\
\text { performed } \\
\text { indepen- } \\
\text { dently }\end{array}$} & \multicolumn{2}{|c|}{ Men } & \multicolumn{2}{|c|}{ Women } \\
\hline & $\mathrm{n}$ & $\%$ & $\mathrm{n}$ & $\%$ & & $\mathrm{n}$ & $\%$ & $\mathrm{n}$ & $\%$ \\
\hline \multirow{3}{*}{$\begin{array}{l}\text { Severe } \\
\text { functional } \\
\text { impairment }\end{array}$} & \multirow{3}{*}{47} & \multirow{3}{*}{17.80} & \multirow{3}{*}{205} & \multirow{3}{*}{23.56} & 0 & 15 & 5.68 & 60 & 6.90 \\
\hline & & & & & 1 & 11 & 4.17 & 67 & 7.70 \\
\hline & & & & & 2 & 21 & 7.95 & 78 & 8.97 \\
\hline \multirow{2}{*}{$\begin{array}{l}\text { Moderate } \\
\text { functional } \\
\text { impairment }\end{array}$} & \multirow[b]{2}{*}{62} & \multirow[b]{2}{*}{23.48} & \multirow[b]{2}{*}{199} & \multirow[b]{2}{*}{22.87} & 3 & 24 & 9.09 & 87 & 10.00 \\
\hline & & & & & 4 & 38 & 14.39 & 112 & 12.87 \\
\hline \multirow{2}{*}{$\begin{array}{l}\text { Fully } \\
\text { functional }\end{array}$} & \multirow{2}{*}{155} & \multirow{2}{*}{58.72} & \multirow{2}{*}{466} & \multirow{2}{*}{53.57} & 5 & 59 & 22.35 & 197 & 22.65 \\
\hline & & & & & 6 & 96 & 36.36 & 269 & 30.92 \\
\hline
\end{tabular}

$M-4.3 ; S D-1.8$ for men; $M-4.1 ; S D-1.9$ for women.

Differences are statistically significant $(t=2.035 ; p=0.042)$.

Quality of Life. Both genders evaluated their general, physical and psychological health significantly lower (means $<3$ ) than their overall quality of life, social relationships and environment (means > 3) according to the WHOQOL-BREF.

All the quality of life domains and almost all the facets in the domains were evaluated significantly lower by women than men $(\mathrm{p}<0.05)$. The only exceptions with a similar score for both genders referred to: 'social support' $(\mathrm{p}=0.203)$, 'health
Table 4. Abbreviated Mental Test Score (AMTS) results at advanced age

\begin{tabular}{|c|c|c|c|c|c|c|c|c|c|}
\hline \multirow{2}{*}{$\begin{array}{l}\text { Cognitive } \\
\text { impairment }\end{array}$} & \multicolumn{2}{|c|}{ Men } & \multicolumn{2}{|c|}{ Women } & \multirow{2}{*}{$\begin{array}{l}\text { No. of correct } \\
\text { answers }\end{array}$} & \multicolumn{2}{|c|}{ Men } & \multicolumn{2}{|c|}{ Women } \\
\hline & $\mathrm{n}$ & $\%$ & $\mathrm{n}$ & $\%$ & & $\mathrm{n}$ & $\%$ & $\mathrm{n}$ & $\%$ \\
\hline \multirow{4}{*}{ Severe } & \multirow{4}{*}{19} & \multirow{4}{*}{7.20} & \multirow{4}{*}{84} & \multirow{4}{*}{9.66} & 0 & 4 & 1.52 & 20 & 2.30 \\
\hline & & & & & 1 & 2 & 0.76 & 16 & 1.84 \\
\hline & & & & & 2 & 3 & 1.14 & 18 & 2.07 \\
\hline & & & & & 3 & 10 & 3.79 & 30 & 3.45 \\
\hline \multirow{3}{*}{ Moderate } & \multirow{3}{*}{43} & \multirow{3}{*}{16.29} & \multirow{3}{*}{192} & \multirow{3}{*}{22.08} & 4 & 7 & 2.65 & 44 & 5.06 \\
\hline & & & & & 5 & 16 & 6.06 & 72 & 8.28 \\
\hline & & & & & 6 & 20 & 7.58 & 76 & 8.74 \\
\hline \multirow{2}{*}{ Mild } & \multirow{2}{*}{59} & \multirow{2}{*}{22.35} & \multirow{2}{*}{265} & \multirow{2}{*}{30.34} & 7 & 28 & 10.61 & 113 & 12.99 \\
\hline & & & & & 8 & 31 & 11.74 & 152 & 17.47 \\
\hline \multirow{3}{*}{$\begin{array}{l}\text { Normal } \\
\text { state }\end{array}$} & \multirow{3}{*}{143} & \multirow{3}{*}{54.17} & \multirow{3}{*}{329} & \multirow{3}{*}{37.82} & 9 & 44 & 16.67 & 115 & 13.22 \\
\hline & & & & & 10 & 42 & 15.91 & 101 & 11.61 \\
\hline & & & & & 11 & 57 & 21.59 & 113 & 12.99 \\
\hline
\end{tabular}

$M-8.1 ; S D-2.6$ for men; $M-7.4 ; S D=2.7$ for women.

Differences are statistically significant $(t=3.819 ; \mathrm{p}<0.001)$.

and social care: accessibility and quality' $(\mathrm{p}=0.086)$ and 'thinking, learning, memory and concentration' $(p=0.063)$ (Fig. 1).

Quality of life determinants. Categorical factors other than gender that were found to be correlated with quality of life are presented in Table 5. Overall quality of life, general, physical and psychological health, social relationships and environment were evaluated significantly lower by urban inhabitants than rural inhabitants, lower by widowed individuals than married respondents, lower by respondents living alone than respondents living with families, lower by respondents with chronic pain and geriatric giants. Only psychological health was evaluated lower by respondents with no school education than by respondents with primary or secondary level of education.

Functional impairment affected negatively all the quality of life domains assessment, while cognitive impairment decreased it in only 3 domains: physical and psychological health and social relationships (Tab. 6). The respondent's age (in the analysed range) correlated negatively only with physical health's assessment.

\section{DISCUSSION}

Demographic trends have resulted in unfavourable social and economic changes. Nowadays, $1 / 3$ of the average woman's life takes place after the postmenopausal period, when the risk of many diseases increases. A proper systemic approach to welfare should reflect the existing needs of the elderly and address differences in ageing between genders. This seems particularly important in the light of soaring costs of health and social care caused by increasing prevalence of multi-morbidities and disabilities. Other concerns refer to weakening family ties and intergenerational interactions $[18,19]$.

The study did not indicate any significant differences between genders in terms of age, place of residence or level of education. The major difference referred to marital status, with $89 \%$ of women being widowed against just $56 \%$ among 


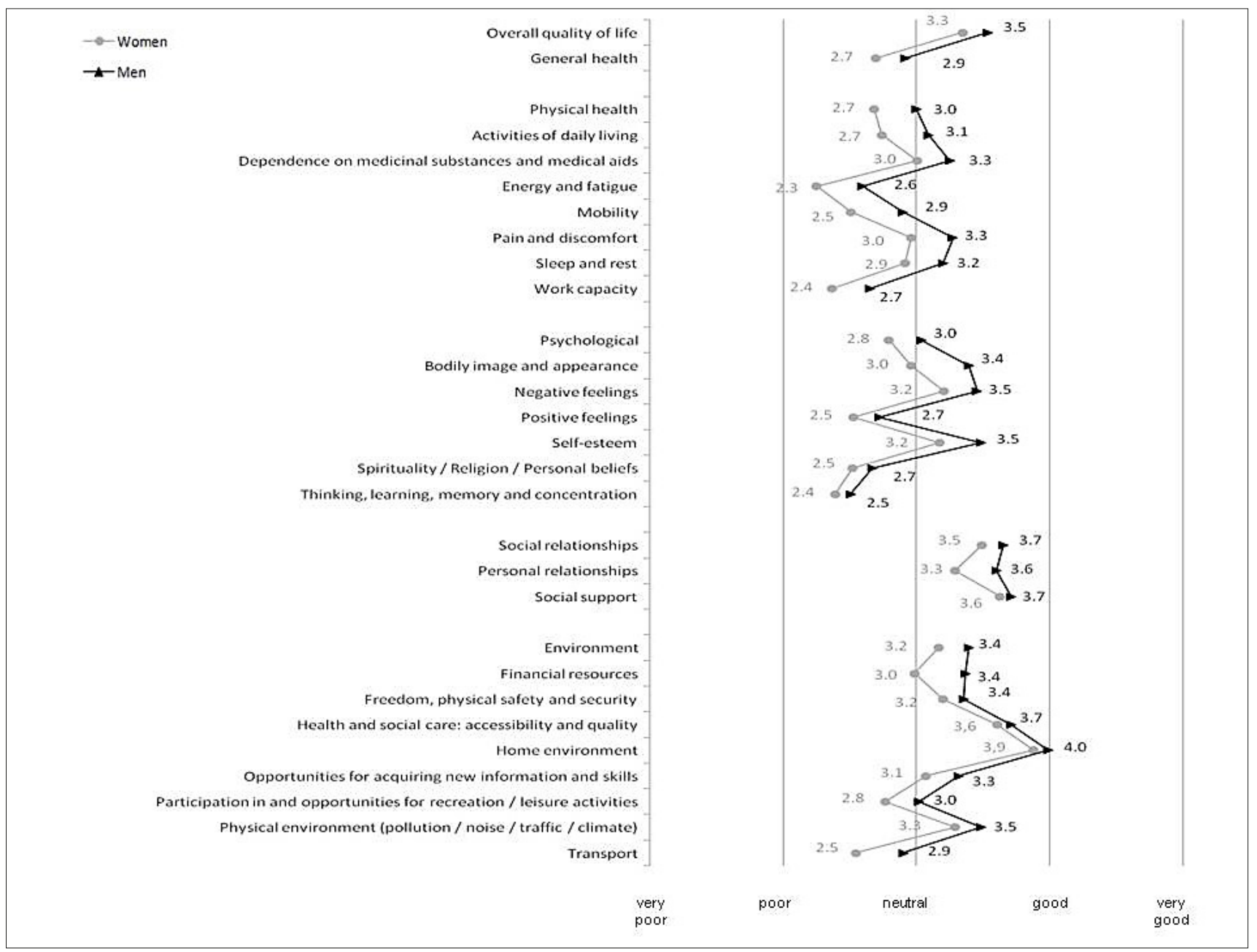

Figure 1. Gender gap in quality of life at advanced age

Notes: The assessment of all the domains and almost all the facets was significantly higher for the men than the women ( $p<0.05)$. The exceptions were 3 facets: 'thinking, learning, memory and concentration' ( $p=0.063)$; 'social support' $(p=0.203)$; 'accessibility and quality of health and social care' ( $p=0.086)-$ the assessment of which was not significantly different between the men and the women.

men. $40 \%$ of the analysed men remained married, while only $4 \%$ of women. This is important, as loneliness may implicate a number of unfavourable processes that negatively impact on health [20]. Official Polish statistics show that $62 \%$ of men aged 80 years or over are married, while the percentage of widowed women is as high as $80 \%$ [21]. Hence, being old may indicate loneliness among women but not necessarily among men.

Health condition of men and women. An Iranian study indicated greater disability among older women than men (5.6\% vs. $4.38 \%$ ); however, the overall disability rates were lower than in highly developed countries [22]. A study from Austria showed daily functionality to be limited among $10-20 \%$ of females, which was more than among males, and in line with the results of the current study [23]. Although the data referred to the $75-84$ age group, the nature of this trend is consistent - females were less functional than males in their daily activities.

The process of ageing is clearly related to a gradual decline in intellectual abilities that accelerates around the age of 75. The Instrumental Activities of Daily Living Scale (iADL) scores typically indicate that $10-30 \%$ of people aged $75-84$ have some deficits in that area. It may reach as much as
$50 \%$ in the oldest groups; however, males scored better than females [23]. In terms of the function of daily life (ADL), an age-related decline is commonly observed.

The percentage of independent persons (ADL scale 5-6 points) in the Polsenior study decreases from $99.9 \%$ at the age of $65-69$ to $79.1 \%$ in the oldest age group of 90 years and more. Women aged 85 and over were less fit on the ADL scale than men of the same age. In the current study, women aged 90 and over remained independent in $53.45 \%$ (5-6 points on the ADL scale), slightly worse than men of the same age (58.72\%). This association has also been confirmed by the Polsenior study [24].

The Abbreviated Mental Test Score (AMTS) delivers more mixed results with regard to differences between genders. In a group of Polish patients residing in a nursing home, Glowacka et al. [25] demonstrated that men had slightly better AMTS results. However, the sample was small (94 participants) with male participants younger on average than females (69 years vs 80 years). A study by Slusarska et al. [26] found that females were more likely to obtain normal scores (no impairment) than the males (40.6\% vs. $24.7 \%)$. The study was again substantially smaller and the participants were younger than those in the presented group (101 participants aged 65-75). Kim and Park found in a Korean population 
Table 5. WHO quality of life domains vs. categorical demographic and health conditions at advanced age

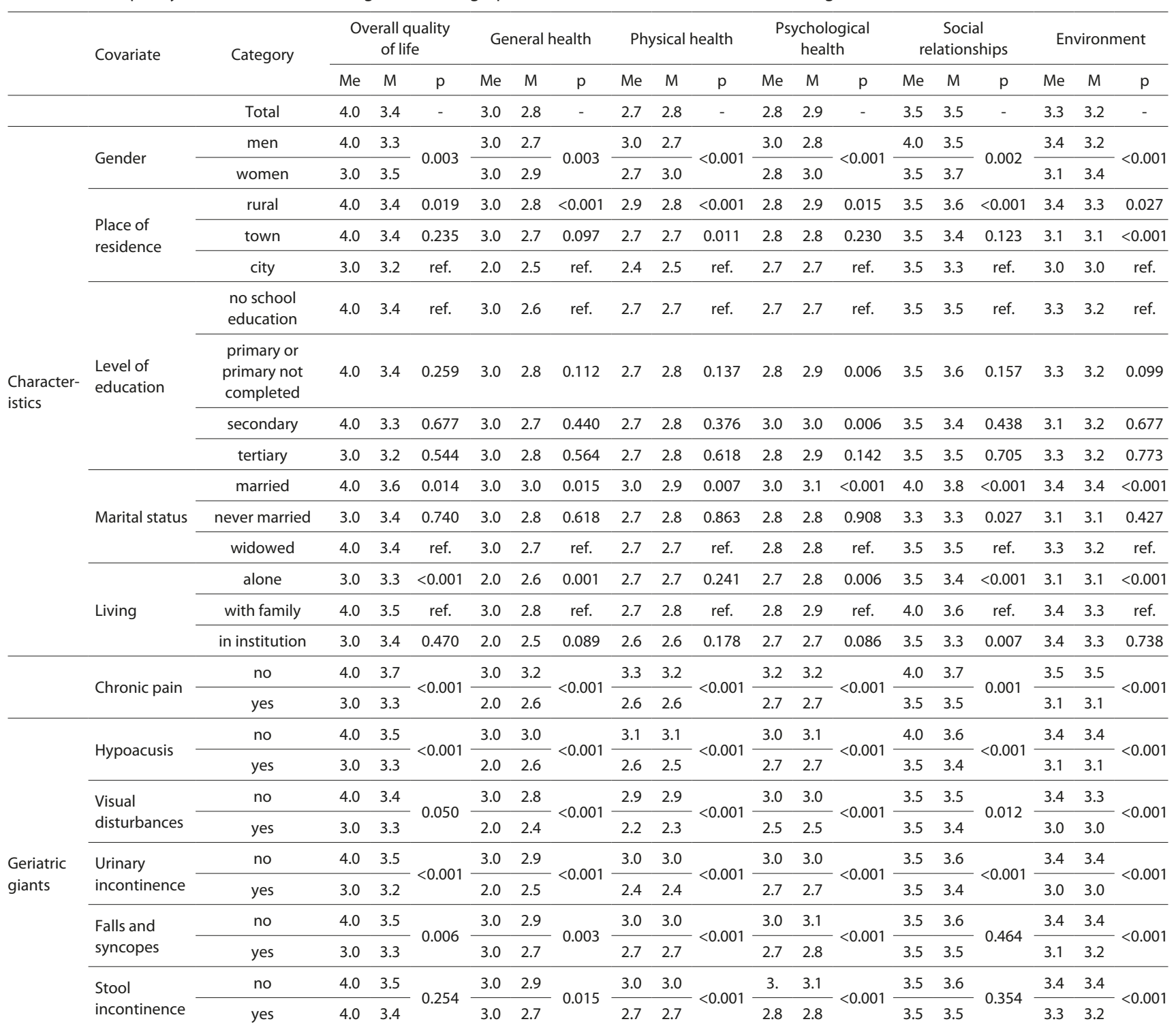

ref. - reference category for categorical covariates; Me - median; M - mean quality of life (1 - very poor, 2 - poor, 3 - neutral, 4 - good, 5 - very good).

Table 6. Correlations between WHO quality of life domains and age, ADL and AMTS at advanced age.

\begin{tabular}{|c|c|c|c|c|c|c|c|c|c|c|c|c|c|}
\hline \multirow[t]{2}{*}{ Covariate } & \multirow[t]{2}{*}{ Category } & \multicolumn{2}{|c|}{$\begin{array}{l}\text { Overall quality } \\
\text { of life }\end{array}$} & \multicolumn{2}{|c|}{ General health } & \multicolumn{2}{|c|}{ Physical health } & \multicolumn{2}{|c|}{$\begin{array}{l}\text { Psychological } \\
\text { health }\end{array}$} & \multicolumn{2}{|c|}{$\begin{array}{l}\text { Social } \\
\text { relationships }\end{array}$} & \multicolumn{2}{|c|}{ Environment } \\
\hline & & $r$ & $\mathrm{p}$ & $r$ & $\mathrm{p}$ & $r$ & $\mathrm{p}$ & r & $\mathrm{p}$ & $r$ & $\mathrm{p}$ & $r$ & $\mathrm{p}$ \\
\hline $\mathrm{ADL}$ & daily living activities performed independently & 0.165 & $<0.001$ & 0.266 & $<0.001$ & 0.472 & $<0.001$ & 0.366 & $<0.001$ & 0.146 & $<0.001$ & 0.291 & $<0.001$ \\
\hline AMTS & correct answers & 0.057 & 0.074 & 0.033 & 0.304 & 0.073 & 0.022 & 0.085 & 0.008 & 0.062 & 0.050 & 0.055 & 0.086 \\
\hline
\end{tabular}

$r$-Pearson's correlation coefficient.

study that the MMSE value was worse for women than for men [27]. Previous results showed that undetected cases of dementia exceed $50 \%$ of people suffering from this disorder in the community [28]. This is a known phenomenon worldwide. The extent of under-detection of dementia as well as its causes are still not reported. It is obvious, however, that detecting people living with dementia is crucial for proper care and treatment. Results of the corrent study also indicate a significant number of people with cognitive impairment who had not previously been diagnosed with dementia. Moderate cognitive impairment was found in approx. $22 \%$ of analyzed males, whereas approx. $32 \%$ of females, and severe cognitive impairment in $7 \%$ of males and almost $10 \%$ of females. These cases should be suspected of dementia and indicate a high percentage of undiagnosed or misdiagnosed dementia. This is a well known phenomenon worldwide. Nowadays, early diagnosis of cognitive impairment is considered crucial, taking into consideration various aspects: QoL, providing 
adequate support and prevention of dementia [29]. A metaanalysis of 23 studies demonstrated that studies reporting under-detection of dementia in the community concerned mainly high-income countries, and none were performed in low-income countries [30]. The authors observed that among older adults, men and people with dementia at earlier ages had higher risk of undetected dementia.

The so-called geriatric giants are a collective term for various impairments prevalent in the elderly [31, 32]. It seems natural that elderly males are less prone to urinary incontinence, but differences are not as significant as in other areas. A Scandinavian study of 5,474 people aged 70 or more (mean age of $76.57 \%$ of females) showed that women were significantly more likely to suffer from the syndrome ( $29 \%$ vs. $23.3 \%$ of men), but not quite as likely with respect to falls ( $40.7 \%$ vs. $27.8 \%$ of men, $\mathrm{p}<0.0001)$ [33]. The authors also pointed out that participants suffering from urinary incontinence were more likely to fall $[33,34]$. In the women analysed in the current study, in all but one, the geriatric giants were more common than in men. Only hearing disturbance was demonstrated to be present with similar prevalence in both genders.

An Austrian study [23] demonstrated a worse overall health condition among women, and a higher prevalence of most somatic diseases associated with old age. Women reported serious pain more frequently than men, which is in line with the current finding of $76 \%$ of women reporting chronic pain, compared with $60 \%$ of males. These results are very consistent to those presented in this study. Somewhat different findings were obtained by another Polish study that found males to suffer more frequently from faecal incontinence $(29.5 \%$ vs. $26.3 \%)$ and problems with vision (45\% vs. $38.1 \%)$. However, due to younger age of participants $(\mathrm{N}=506,60$ years or over), the group was not entirely comparable [35]. The age-wise comparison revealed that - in line with the current findings - elderly males enjoyed better health than elderly females.

Quality of life in elderly men and women. The results of the WHOQOL-BREF survey from this study showed rather low levels of general health satisfaction. Men rated it at 2.9 points while women at 2.7, on average. Men also rated higher their physical health, (3.0 vs 2.7 ) and general quality of life (3.5 vs 3.3).

Similar findings were reported by Winkler et al. [23] who found that among seniors aged 75 or over, $35.5 \%$ of females rated their health as good or very good ( $43.8 \%$ among men) and $20.1 \%$ as bad or very bad ( $18.6 \%$ among men). The same association referred to quality of life with $58.3 \%$ of men rating it as good or very good ( $48.8 \%$ among women) and $11 \%$ as bad or very bad (14.7\% among women). Despite age differences, the finding of men rating their life and health better than women seems very consistent across both studies. Other data suggest that quality of life can be satisfactory even at older age. The PolSenior study [24] which covered 3,027 seniors: 1,066 aged 80 or over (303 aged 90 or over) reported that $64.2 \%$ of males and $54.4 \%$ of females subjectively evaluated the quality of their lives as good or very good, with only $4.6 \%$ and $6.6 \%$, respectively, considering it bad or very bad. Men also rated better their physical and psychological health. Meanwhile, women performed better only in the domain of social relationships, which was in line with the results of the current study.
Quality of life determinants at advanced age. Some clear and understandable findings refer to geriatric giants that were all (along with chronic pain) found to negatively affect the quality of life. This is consistent with other literature that indicated associations of lower life quality with falls and fear of further falls [36], or impaired vision and hearing [37]. The results of this study show that advanced age has a negative effect on quality of life assessment. This phenomenon may certainly be associated with the prevalence chronic diseases, which is confirmed by other studies [21, 38, 39].

The quality of life score is strongly correlated with place of residence. The EUROFOUND study [40] found that quality of life, in general, was rated higher in rural regions of some countries such as Austria, Czech Republic, France, Germany and theUnited Kingdom. This is was also found in the current study; however, EUROFOUND placed Poland in the group countries with no clear differences between rural and urban areas for most indicators.

Previously, some interesting findings presented associations between health condition, chronic diseases, quality of life with level of education. A study on the elderly in Austria found that those with a higher education demonstrated better health, had a better life quality, and less frequently experienced health problems [23]. In turn, the current study confirmed such correlation only in the psychological domain.

An important finding from the presnted study is that married participants rated all the life quality domains significantly higher $(\mathrm{p}<0.05)$ than those who were widowed or single. Other studies [39] confirm this phenomenon, indicating that marriage or a relationship may be the key to living a higher quality life at advanced age. This, to some extent, may explain the finding that $90+$ men live better quality lives that $90+$ women, since the former were married much more frequently ( $40 \%$ vs. $4 \%$ ). The nature of this association cannot be determined based on the available data and could be investigated by future studies. Importantly, other studies also suggest that active leisure over the long term may contribute to increased quality of life among the oldest age group [41].

An additional important predicting factor of the quality of life was staying fit, which suggests that the quality of life is indeed more about 'adding life to years, not just more years to life [42].

\section{CONCLUSIONS}

The study supports evidence that $90+$ men assess their health better than $90+$ women, and that their quality of life is not affected as much by old age as in women.

The single most important factor found to positively correlate with quality of life was being married. Others factors include: place of residence (rural), living with a family, lack of geriatric giants.

It is necessary to promote women's physical and mental activity at the start of their ageing in order to decrease the gender gap in health condition and the quality of life at advanced age.

Future studies may focus on investigating the cause and effect relationship between quality of life and being married at advanced age. 
Strengths and limitations. This study is subject to certain limitations. First, there is a risk of selection bias as data were collected through Social Support Centres. However, the sample group was fairly large considering the age criterion, and had an almost identical gender structure $(76.72 \%$ vs. $23.28 \%)$ as the general Polish population aged $90+(76.1 \%$ vs. $23.9 \%$ ) [43].

Second, it cannot be excluded that the results are somewhat biased as seniors requiring or seeking support from the centres may live lower quality lives than those who do not seek such help. On the other hand, participants not able to communicate in a logical manner were excluded. Mild or severe cognitive impairment may also have biased the results; however, it was required that all participants scoring below 4 AMTS points be assisted by family members or carers familiar with their health and living conditions.

To the best knowledge of the authors, this is one of the largest studies of people aged 90 or over.

\section{Conflicts of interest}

Authors have no conflicts of interests to declare.

\section{REFERENCES}

1. European Commission. The 2012 Ageing Report - Economic and budgetary projections for 27 EU Member States (2010-2060). European Economy 2/2012. ec.europa.eu/economy_finance/publications/../ee2012.

2. Healthy life years, life expectancy statistics. Eurostat 2018. http:// appsso.eurostat.ec.europa.eu/nui/show.do?dataset=hlth_hlye\&lang=en

3. Thomas PA. Gender, social engagement, and limitations in late life. Social Science \& Medicine Volume 2011; 73(9): 1428-143.

4. Health at a Glance: Europe - Life expectancy and healthy life expectancy at birth, OECD iLibrary 2012: Statistics, www.oecdbetterlifeindex. org/.../united-kingdom/2012

5. Life expectancy at birth, male, females (years). World Bank 2018. https:// data.worldbank.org/indicator/SP.DYN.LE00.MA.IN?locations=EU

6. Sundberg L, Agahi N, Fritzell J, Fors S. Why is the gender gap in life expectancy decreasing? The impact of age- and cause-specific mortality in Sweden 1997-2014. Int J Public Health 2018; 63(6): 673-681. doi: 10.1007/s00038-018-1097-3

7. Luy M, Wegner-Siegmundt C. The impact of smoking on gender differences in life expectancy: more heterogeneous than often stated. Eur J Public Health 2015; 25: 706-710. doi: 10.1093/eurpub/cku211

8. Austad SN. Sex differences in health and aging: a dialog between the brain and gonad? GeroScience 2019; 41: 267-273.

9. Zhang Y, Wu L, Wang Y, Zhang M, Li L, Zhu D. et al. Protective Role of Estrogen-induced miRNA-29 Expression in Carbon Tetrachlorideinduced Mouse Liver Injury. The Journal of Biological Chemistry 2012; 287: 14851-14862. doi: 10.1074/jbc.M111.314922

10. Loef $M$, Walach $H$. The combined effects of healthy lifestyle behaviors on all cause mortality: a systematic review and meta-analysis. Prev Med 2012; 55: 163-170. doi: 10.1016/j.ypmed.2012.06.017

11. Iorga A, Cunningham CM, Moazeni S, Ruffenach G, Umar S, Eghbali M. The protective role of estrogen and estrogen receptors in cardiovascular disease and the controversial use of estrogen therapy. Biology of Sex Differences 2017; 8(33): 1-16.

12. Kulik TB, Janiszewska M, Piróg E, Pacian A, Stefanowicz A, Żołnierczuk-Kieliszczek D. et al. Sytuacja zdrowotna osób starszych w Polsce i innych krajach europejskich [The health situation of older people in Poland and other European countries]. Medycyna Ogólna i Nauki o Zdrowiu [General Medicine and Health Science] 2011; 17(2): 90-95 (in Polish).

13. Sytuacja demograficzna osób starszych i konsekwencje starzenia się ludności Polski w świetle prognozy na lata 2014-2050. Główny Urząd Statystyczny, Warszawa, 2014.

14. Pinkas J, Gujski M, Humeniuk E, Raczkiewicz D, Bejga P, Owoc A, et al. State of health and quality of life of women at advanced age. Medical Science Monitor 2016; 22: 3095-3105.
15. Shelkey M, Wallace M. Katz index of independence in activities of daily living (ADL). Try this, Best Practices in Nursing Care to Older Adults International Journal of Older People; Issue Number 2, Revised 2012

16. Romanik W, Łazarewicz M. The Polish version of the Abbreviated Mental Test Score (AMTS) - methodology issues. Psychiatr Psychol Klin 2017; 17(3): 203-207. doi: 10.15557/PiPK.2017.0024

17. Skevington SM, Lotfy M, O'Connell KA. The World Health Organization's WHOQOL-BREF quality of life assessment: Psychometric properties and results of the international field trial. A report from the WHOQOL group. Qual Life Res 2004; 13: 299-310.

18. Piniero-Rodriges M.A, Facchini A, Thume E, Maia F. Gender and incidence of functional disability in the elderly: a systematic review. Cadernos de Saude Publica 2009; 25(3): 464-476.

19. European Year for Active Ageing and Intergenerational Solidarity 2012. European Parliament 2011, www.europarl.europa.eu/news/pl/ news-room/content/20110314IPR15479012

20. Luo Y, Hawkley LC, Waite LJ, \& Cacioppo JT. Loneliness, health, and mortality in old age: A national longitudinal study. Soc Sci Med. 2012; 74: 907-914. doi: 10.1016/j.socscimed.2011.11.028

21. Sytuacja demograficzna osób starszych i konsekwencje starzenia się ludności Polski w świetle prognozy na lata 2014-2050 [Demographic situation of the elderly and consequences of the aging of the Polish population according to the forecast for 2014-2050], Central Statistical Office in Poland, Warsaw 2014 (in Polish).

22. Noei H, Sahaf R, et al. The Relationship between gender and disability in the eldery people in Tehran municipality pension organization. Iranian Journal of Ageing 2017; 12(1): 6-15.

23. Winkler P, Pochobradsky E, Wirl Ch. Gesundheit und Krankheit der älteren Generation in Österreich [Health and disease of the older generation in Austria]. Wien 2012 (in German).

24. Mossakowska M, Więcek A, Błędowski P. Aspekty medyczne, psychologiczne, socjologiczne i ekonomiczne starzenia się ludzi w Polsce - Polsenior. Część 1. Rozdział 4. Przebieg badania - Badania dodatkowe [Medical, psychological, sociological and economic aspects of the aging of people in Poland - Polsenior - Part 1. Chapter 4. The course of the study - Additional tests]. Termedia Wydawnictwa Medyczne Poznań 2012 (in Polish).

25. Głowacka M, Mitura K, Kornatowski T, Haor B, Zabielska P, Biercewicz $\mathrm{M}$, et al. Mental capacity of elderly people according to the AMTS as shown on the example of nursing home residents. Gerontologia Polska 2017; 25: 223-228.

26. Slusarska B, Nowicki GJ, Bartoszek A, Wittwer S, Zboina B, Naylor K. Health problems of the elderly aged 65-75 years supervised community nurse. Gerontologia Polska 2016; 24: 17-25.

27. Kim JL, Park JH, KimBJ, Kim MD. Interactive influences of demographics on the Mini-Mental State Examination (MMSE) and the demographics-adjusted norms for MMSE in elderly Koreans. International Psychogeriatrics 2011; 24(4): 642-650.

28. Connolly A, Gaehl E, Martin H, Morris J, Purandare N. Underdiagnosis of dementia in primary care: variations in the observed prevalence and comparisons to the expected prevalence. Aging Ment Health. 2011; 15(8): 978-984. doi: 10.1080/13607863.2011.596805

29. Jitapunkul S, Chansirikanjana S, Thamarpirat J. Undiagnosed dementia and value of serial cognitive impairment screening in developing countries: A population-based study. Geriatr Gerontol Int. 2009; 9: 47-53.

30. Lang L, Clifford A, Wei L, Zhang D, Leung D, Augustine G, Danat IM, Zhou W, Copeland JR, Anstey KJ, Chen R. Prevalence and determinants of undetected dementia in the community: a systematic literature review and a meta-analysis. BMJ Open. 2017 Feb 3; 7(2): e011146. doi: 10.1136/bmjopen-2016-011146

31. Inouye SK, Studenski S, Tinetti ME, \& Kuszel GA. Geriatric Syndromes: Clinical Research and Policy Implications of a Core Geriatric Concept. Journal of American Geriatric Society 2007; 55(5): 780-791.

32. Cruz-Jentoft AJ, Landi F, Topinkova E. Understanding sarcopenia as a geriatric syndrome. Current Opinion in Clinical Nutrition Metabolic Care $2010 ; 13(1): 1-7$

33. Foley AL, Loharuka S, Barrett JA, Mathews R, Williams K, McGrother CW. Association between the Geriatric Giants of urinary incontinence and falls in older people using data from the Leicestershire MRC Incontinence Study. Age and Ageing Jan 2012; 41(1): 35-40. doi: 10.1093/ ageing/afr125

34. Kamińska MS, Brodowski J, Karakiewicz B. Fall Risk Factors in Community-Dwelling Elderly Depending on Their Physical Function, Cognitive Status and Symptoms of Depression. Int J Environ Res Public Health. 2015: 12(4): 3406-3416. doi: 10.3390/ijerph120403406 
35. Talarska D, Kropińska S, Strugała M, Szewczyczak M, Tobis S, Wieczorowska-Tobis $\mathrm{K}$. The most common factors hindering the independent functioning of the elderly at home by age and sex. European Review for Medical and Pharmacological Sciences 2017; 21: 775-785.

36. Mane AB, Sanjana T, Patil PR, Sriniwas T. Prevalence and correlates of fear of falling among elderly population in urban area of Karnataka, India. J Midlife Health. 2014 Jul-Sep; 5(3): 150-155.

37. Shiran Z, Moyes S, McLean C, Serchfield G, Welch D, Jacobs R, et al Self-reported hearing, vision and quality of life: older people in New Zealand. Australian Asian Journal of Ageing 2016; 35(2): 98-105.

38. Burzyńska M, Kępa M, Bryła M, Maniecka-Bryła I. Samoocena stanu zdrowia i zachowań zdrowotnych starszych mieszkańców wsi [Selfassessment of health status and health behaviours of older rura inhabitants]. In P. Szukalski (Ed). Starzenie się ludności a solidarność międzypokoleniowa [Aging of the population and intergenerational solidarity] (pp.181-195). University of Lodz 2014 (in Polish).
39. Keevil LV, Romero-Ortuno R. Ageing well: a review of sarcopenia and frailty. Proceedings of the Nutrition Society 2015; 74(4): 337-347.

40. Quality of Life in Urban and Rural Europe. European Foundation for the Improvement of Living and Working Conditions. EUROFOUND. Cornell University ILR School 2014 https://digitalcommons.ilr.cornell. edu/cgi/viewcontent.cgi?article=1420\&context=intl

41. Silverstein M, Parker MG. Leisure Activities and Quality of Life among the Oldest Old in Sweden. Research on Ageing 2012. https:// doi.org/10.1177/0164027502245003

42. Begg S.J. Health in a 'post-transition' Australia: adding years to life or life to years? Australian Health Review 2013; 38(1): 1-5.

43. Struktura ludności według wieku w latach 1970-2050. Główny Urząd Statystyczny. https://stat.gov.pl/obszary-tematyczne/ludnosc/ludnosc/ ludnosc-piramida/ 